\title{
Krill larvae, copepods and the microbial food web: interactions during the Antarctic fall
}

\author{
Stephen A. Wickham ${ }^{1,3, *}$, Ulrike-G. Berninger ${ }^{2,3}$ \\ ${ }^{1}$ Zoological Institute, University of Cologne, Weyertal 119, 50923 Cologne, Germany \\ ${ }^{2}$ Biological Oceanography, Alfred Wegener Institute of Polar and Marine Research, Am Handelshafen 12 , \\ 27570 Bremerhaven, Germany
}

${ }^{3}$ Present address: Department of Organismal Biology, University of Salzburg, Hellbrunnerstr. 34, 5020 Salzburg, Austria

ABSTRACT: Experiments were run in the Antarctic Bellinghausen Sea during the austral fall to ascertain the interactive effects of krill larvae (furcilia) and copepods on the microbial food web. A cross-classified design with addition of the small cyclopoid copepod Oithona similis and either the furcilia larvae of Euphausia superba or the calanoid copepod Metridia gerlachei to the natural planktonic community was used, as well as a single experiment with varying densities of $O$. similis. The experiments showed furcilia to have much higher grazing rates on copepods and ciliates than on algae, with positive selection for ciliates that was not influenced by the presence or absence of $O$. similis. $M$. gerlachei had a grazing impact on ciliates that was much less than that of furcilia larvae, but due to a high taxonomic resolution of the ciliate community it could be shown that there were groups of grazing-vulnerable and -resistant forms. Contrary to expectations, $O$. similis had very low grazing rates on both ciliates and algae, but here too grazing-vulnerable and -resistant groups of ciliates could be distinguished. Neither the very strong impact of furcilia on ciliates, copepods and algae nor the more moderate impact of $M$. gerlachei cascaded down to heterotrophic and phototrophic nanoplankton or to bacteria. At least at the time of our experiments, ciliates were tightly bound to the 'classic' aquatic food web, but do not serve to transmit a trophic cascade from the classic and microbial food webs.

KEY WORDS: Ciliate · Grazing · Antarctica $\cdot$ Copepod · Krill $\cdot$ Furcilia $\cdot$ Trophic cascade

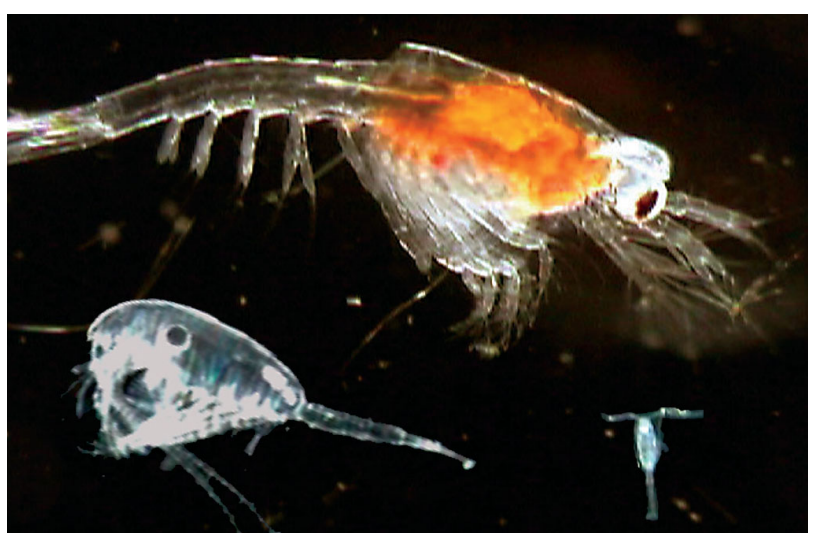

Experiments conducted in the Bellinghausen Sea (Antarctica) during the austral autumn show that krill larvae (Euphausia superba furcilia, top) have much higher grazing rates on copepods (Metridia gerlachei, lower left; Oithona similis, lower right) and ciliates than on algae. Trophic levels beneath ciliates did not respond to the addition of furcilia, suggesting that top-down control of the microbial food web is minimal during the Antarctic autumn.

Photo: Stephen Wickham

\section{INTRODUCTION}

That microbial food webs play an integral role in aquatic systems has over the last $20 \mathrm{yr}$ developed into a paradigm. In Antarctic waters, the microbial food web takes on particular importance in that the growing season of autotrophs is short, and for much of the year the system is net heterotrophic, with bacterial secondary production exceeding primary production (Rivkin 1991). In the Antarctic autumn and winter, heterotrophic protozoan biomass can match or exceed 
phytoplankton biomass (Garrison et al. 1993), making protozoans a potentially important food source for meso- and macroplankton. Copepods have long been know to feed on ciliates and, to a lesser extent, flagellates, with these protists often making up a substantial proportion of copepods' diets (Sanders \& Wickham 1993). Preying on ciliates or other heterotrophic protozoans could give copepods which continue to feed during winter the possibility to continue to meet their metabolic demands without entering diapause.

The euphausiid Euphasia superba (hereafter referred to as 'krill') has long been known as a keystone herbivore in the Southern Ocean and has in recent years become acknowledged as a predator of copepods and ciliates (Price et al. 1988, Froneman et al. 1996, Atkinson \& Snÿder 1997, Perissinotto et al. 2000). This gives krill the opportunity to access heterotrophic food sources, which have been shown to contribute on average $79 \%$ (and at times nearly 100\%) to krill gut contents (Perissinotto et al. 2000). Ciliates, particularly the oligotrichs (sensu lato) that are often the dominant planktonic ciliate group, graze mainly the nano- and picoplanktonic size classes not otherwise available to krill (Jonsson 1986, Kivi \& Setälä 1995). Thus, krill grazing directly on ciliates would lead to a more efficient biomass transfer from lower to higher trophic levels than if copepods were a necessary intermediate step.

Considerably less is known of the feeding preferences of the furcilia larval stage of krill (hereafter simply 'furcilia'). Omnivorous feeding has been shown, with both ciliates and copepods found in the diet, and has been hypothesized as an over-wintering strategy for furcilia (Daly 1990, Meyer et al. 2002, Daly 2004, Pakhomov et al. 2004). When both copepods and ciliates are abundant, it is not clear whether larval or adult krill show any preference for one group over the other, or have a switching strategy dependent on the relative abundance of different prey groups. Understanding feeding preferences of furcilia is critical not only for understanding krill ecology or the importance of omnivory in aquatic food webs, but also for understanding the impacts of higher trophic levels on the microbial food web. If the copepod-ciliate link is the main path through which microbial production leaves the microbial food web, and krill graze much more on copepods than on ciliates, then high krill abundance will result in a microbial food web that is a biomass sink. On the other hand, if krill are effective ciliate grazers, then microbial production will move more efficiently into higher trophic levels than if an intermediate, copepod trophic level is necessary.

In order to better understand these phenomena, factorial experiments manipulating the presence or absence of furcilia and copepods in natural plankton communities were carried out. With this design, the separate and combined predatory impacts of furcilia and copepods on ciliates and the rest of the microbial food web could be compared. If furcilia and copepods act independently, then their combined predatory impact should be the sum of their impacts when assessed alone. However, if furcilia prey on copepods that would otherwise consume ciliates, or if furcilia prey on ciliates only when copepods are absent, then the combined predatory impact of furcilia and copepods would be less than the sum of their separate impacts.

As a copepod that could potentially serve as both furcilia prey and a ciliate predator, the cyclopoid Oithona similis (hereafter 'Oithona') was chosen. Oithona is often the most abundant copepod in Antarctic waters (Fransz \& Gonzalez 1995), and has been shown to be an effective predator on ciliates (Atkinson 1996, Nakamura \& Turner 1997). Moreover, freshwater research has established that cyclopoids are selective predators on ciliates, with the potential to alter the composition of the ciliate community (Wickham 1995). Experiments with Oithona and the calanoid copepod Metridia gerlachei (hereafter 'Metridia') were conducted to provide a comparison with furcilia. Metridia continues to feed during winter and is known to prey on ciliates as well as other copepods (Atkinson 1996, 1998, Pasternak \& Schnack-Schiel 2001). In addition, a grazing experiment with Oithona alone was conducted, in order to ascertain its impact on ciliates and the rest of the microbial food web independent of the presence of any other metazoan. Experiments were designed to run long enough to observe, if present, a trophic cascade from furcilia or copepods to ciliates and subsequently the rest of the microbial food web. The work was conducted in the Antarctic Bellinghausen Sea during the austral autumn, a time when heterotrophic prey should be becoming relatively more important.

\section{MATERIALS AND METHODS}

Experiments were conducted as part of Cruise ANT XVIII/5b conducted by RV 'Polarstern' in the Bellinghausen Sea, west of the Antarctic peninsula, between 67 and $72^{\circ} \mathrm{S}$ and from 13 April to 7 May 2001, during the Antarctic fall. Copepods and furcilia were captured with $300 \mu \mathrm{m}$-mesh Bongo nets with a $5 \mathrm{l}$ closed cod end, and held in $100 \mu \mathrm{m}$-filtered seawater at $-1^{\circ} \mathrm{C}$ for a minimum of $24 \mathrm{~h}$ to ensure that experimental animals were in good condition. Experiments were run in 2.71 clear polycarbonate bottles, incubated on deck in 5001 tanks with transparent plastic covers that reduced incident photosynthetically active radiation (PAR) by approximately $10 \%$. The bottles were free to move in the tanks, allowing the natural motion of the ship to 
keep particles in the bottles in suspension. Seawater was pumped through the tanks to maintain a constant, near in situ temperature. Incubation water was warmed slightly as it passed through the ship, but remained between -0.9 and $2.4^{\circ} \mathrm{C}$. The water for the experiments was collected in 121 Niskin bottles from $10 \mathrm{~m}$ or $20 \mathrm{~m}$ water depth. Water was drawn off immediately, filtered through a $100 \mu \mathrm{m}$ mesh to remove most mesozooplankton, and stored until use in 241 polycarbonate carboys under low light at $-1^{\circ} \mathrm{C}$. The copepods and furcilia used in the experiments were picked individually under a dissecting microscope with a largebore pipette, and added to the experimental bottle along with a small volume (ca. $20 \mathrm{ml}$ ) of filtered water. There were either 4 (furcilia-Oithona and MetridiaOithona experiments) or 3 (Oithona experiment) replicates per treatment combination.

A total of 4 experiments were carried out. Two experiments used a cross-classified design to examine the direct and indirect effects of furcilia and Oithona. The treatment combinations were furcilia alone (2.9 ind. $\mathrm{l}^{-1}$ ), Oithona alone (first experiment: 15 ind. $\mathrm{l}^{-1}$; second experiment: 20 ind. $\mathrm{l}^{-1}$ ), both furcilia and Oithona together, or both absent. These experiments were run for 64 and $66 \mathrm{~h}$, respectively. The furcilia used in the first experiment were third-stage larvae (FIII), while those in the second experiment were a combination of third- and fourth-stage larvae (FIII and FIV). A third experiment was similar to the furciliaOithona experiments in purpose and design, but in place of furcilia, the calanoid copepod Metridia ger- lachei (2.9 ind. $\mathrm{l}^{-1}$ ) was used. This experiment was of $70 \mathrm{~h}$ duration. The fourth experiment was designed to measure the impact of Oithona on microbial food webs, had as treatments either $0,4,8,16$ or 32 ind. $\mathrm{l}^{-1}$. The Oithona used in this and other experiments were late-stage copepodites and adults without egg sacs. The fourth experiment was run for $48 \mathrm{~h}$. Dates, locations, durations and experimental designs are summarized in Table 1, and the initial concentrations of the organisms examined in the experiments are given in Table 2 .

At the beginning and end of the experiments, samples were taken for zooplankton $(1100 \mathrm{ml})$, chlorophyll a (chl a) (500 ml), ciliates and dinoflagellates $(1000 \mathrm{ml})$, phototrophic and heterotrophic organisms (predominantly flagellates) in the nanoplankton size class (PNAN and HNAN, respectively) and bacteria (together $100 \mathrm{ml}$ ). In all but the Oithona grazing experiment (see below), bacterial and flagellate samples were also taken at the mid-point of the experiments. Bacteria and flagellates were fixed in $2 \%$ formaldehyde, ciliates and dinoflagellates in $5 \%$ Bouin's solution, and zooplankton in $5 \%$ buffered formaldehyde (all final concentrations). Chl a samples were filtered onto GF/F filters, frozen, and later analyzed fluorometrically after ethanol extraction. Bacteria and flagellates were filtered onto $0.2 \mu \mathrm{m}$ pore-size black polycarbonate filters and stained with DAPI within a few days of the samples being taken, and then frozen until counted under an epifluorescence microscope (Porter \& Feig 1980). Phototrophs were

Table 1. Date, location and design of experiments

\begin{tabular}{|c|c|c|c|c|}
\hline Expt & Date (2001) & Location & Duration (h) & Manipulation \\
\hline Furcilia-Oithona I & 22 Apr & $71^{\circ} \mathrm{S}, 85^{\circ} \mathrm{W}$ & 64 & $\begin{array}{l}\text { Krill larvae presence/absence }\left(2.9 \text { ind. }^{-1}\right) \\
\text { cross-classified with Oithona presence/absence }\left(15 \text { ind. } \mathrm{l}^{-1}\right)\end{array}$ \\
\hline Furcilia-Oithona II & 1 May & $67^{\circ} \mathrm{S}, 68^{\circ} \mathrm{W}$ & 66 & $\begin{array}{l}\text { Krill larvae presence/absence }\left(2.9 \text { ind. }^{-1}\right) \\
\text { cross-classified with Oithona presence/absence }\left(20 \text { ind. }^{-1}\right)\end{array}$ \\
\hline Metridia-Oithona & $26 \mathrm{Apr}$ & $67^{\circ} \mathrm{S}, 68^{\circ} \mathrm{W}$ & 70 & $\begin{array}{l}\text { Metridia presence/absence }\left(2.9 \text { ind. }^{-1}\right) \\
\text { cross-classified with Oithona presence/absence }\left(20 \text { ind. } \mathrm{l}^{-1}\right)\end{array}$ \\
\hline Oithona grazing & 19 Apr & $67^{\circ} \mathrm{S}, 69^{\circ} \mathrm{W}$ & 48 & $0,4,8,16,32$ ind. $\mathrm{l}^{-1}$ \\
\hline
\end{tabular}

Table 2. Initial concentrations of chl a, phototrophic and heterotrophic nanoplankton (PNAN and HNAN), bacteria, dinoflagelates and ciliates. Values are means of 3 replicates $\pm 1 \mathrm{SD}$

\begin{tabular}{|c|c|c|c|c|c|c|}
\hline Expt & $\mathrm{Chl} a\left(\mu \mathrm{gl}^{-1}\right)$ & $\begin{array}{l}\text { PNAN ml }{ }^{-1} \\
\quad\left(\times 10^{3}\right)\end{array}$ & $\begin{array}{l}\mathrm{HNAN} \mathrm{ml}^{-1} \\
\quad\left(\times 10^{3}\right)\end{array}$ & $\begin{array}{l}\text { Bacteria ml }{ }^{-1} \\
\quad\left(\times 10^{6}\right)\end{array}$ & $\begin{array}{l}\text { Dinoflagellates } \\
\mathrm{ml}^{-1}\end{array}$ & $\begin{array}{c}\text { Ciliates } \\
\mathrm{ml}^{-1}\end{array}$ \\
\hline Furcilia-Oithona I & $0.155 \pm 0.022$ & $1.63 \pm 0.32$ & $0.27 \pm 0.05$ & $0.798 \pm 0.091$ & $0.21 \pm 0.09$ & $0.94 \pm 0.10$ \\
\hline Furcilia-Oithona II & $0.401 \pm 0.026$ & $1.23 \pm 0.77$ & $0.28 \pm 0.05$ & $0.371 \pm 0.057$ & $0.10 \pm 0.01$ & $0.70 \pm 0.08$ \\
\hline Metridia-Oithona & $0.139 \pm 0.021$ & $0.32 \pm 0.09$ & $0.25 \pm 0.16$ & $0.341 \pm 0.100$ & $0.27 \pm 0.07$ & $1.28 \pm 0.30$ \\
\hline Oithona grazing & $0.347 \pm 0.055$ & $1.62 \pm 0.37$ & $0.60 \pm 0.26$ & $0.664 \pm 0.025$ & $0.13 \pm 0.01$ & $0.74 \pm 0.27$ \\
\hline
\end{tabular}


distinguished from heterotrophs by their autofluorescence under blue light.

Ciliate/dinoflagellate samples were concentrated by first settling 11 for $1 \mathrm{wk}$ in graduated cylinders, then by removing the upper $900 \mathrm{ml}$ of sample water. Between 5 and $50 \mathrm{ml}$ of the concentrated sample was then settled again and counted in an inverted microscope. To aid identification, additional ciliate sub-samples were silver-stained using the quantitative protargol stain (QPS) technique, which usually allows identification to genus or species (Montagnes \& Lynn 1987, Skibbe 1994). Ciliates were identified according to Kahl (1930-1935), Lynn \& Montagnes (1988a,b), Lynn \& Small (2000), Montagnes \& Lynn (1991), Montagnes et al. (1988) and Petz et al. (1995). Zooplankton samples were counted and measured under a dissecting microscope. Oithona and Metridia lengths were converted to biomass using the equations of Sabatini \& Kiørboe (1994) and Fransz \& Gonzalez (1997). All surviving furcilia were picked out separately, fixed in $5 \%$ formaldehyde, and measured under a dissecting microscope. Furcilia size was converted to biomass using the equation of Pakhomov et al. (2004).

Data from the Oithona experiment were analyzed using linear regression, while factorial ANOVA was used for the other three experiments. Because there were 2 time-points for bacteria and flagellates in the furcilia-Oithona and Metridia-Oithona experiments, repeated measures ANOVA was used to analyze those data. In order to group the various ciliate taxa and morphotypes into similarly responding groups, disjoint (non-hierarchical) cluster analysis was used, using only species that made up at least $2 \%$ of total ciliate abundance. All analyses were conducted using SAS version 6.12 (SAS Institute 1989).

Clearance rates were calculated in order to estimate the per-predator impact on the prey population. In the Oithona experiment, this was done by calculating the per-day net ciliate or chl a exponential growth rates from beginning to end of the experiment. These growth rates were then regressed against ind. $\mathrm{ml}^{-1}$, and the slope of the regression was clearance rate, with units of $\mathrm{ml}$ ind.-1 $\mathrm{d}^{-1}$ (Lehman \& Sandgren 1985). For the furcilia-Oithona and Metridia-Oithona experiments, clearance rates $(F)$ were calculated as:

$$
F=\ln \left(N_{\text {control }} \times N_{\text {grazer }^{-1}}\right) \times \text { grazer }^{-1} \times \text { duration }^{-1}
$$

$N_{\text {grazer }}$ and $N_{\text {control }}$ are the end prey abundances in treatments with and without the grazer, 'grazer' is the furcilia or Metridia abundance, and 'duration' is the experiment duration. This equation is equivalent to Frost's (1972) calculation of grazing rates, assuming the same initial prey abundance in treatments with and without predators. From the clearance rates, predator selectivity for the different prey types was calculated as Chesson's $\alpha$ and converted to electivity in order to scale selection from -1 to 1 , where 0 is no selection (Chesson 1983). Dinoflagellate abundance

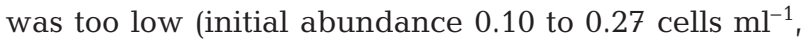
Table 2) to calculate grazing rates with any confidence. As a result, although dinoflagellate abundance data is shown, grazing and selectivity estimates do not include dinoflagellates.

\section{RESULTS}

\section{Furcilia-Oithona experiments}

\section{Experimental conditions}

The 2 furcilia-Oithona experiments were started $9 \mathrm{~d}$ apart but under considerably different conditions. In the first experiment, the initial chl a concentration was less than half, but bacterial numbers twice those found at the beginning of the second experiment (Table 2). Initial total ciliate abundance was 0.94 and 0.70 cells $\mathrm{ml}^{-1}$ in the first and second experiments, respectively, and water temperature averaged $-0.1^{\circ} \mathrm{C}$ (first experiment) and $1.7^{\circ} \mathrm{C}$ (second experiment). In the first experiment, FIII furcilia of mean size $6.35 \mathrm{~mm}$ and biomass $241 \mu \mathrm{g} \mathrm{C} \mathrm{l}^{-1}$ were used. In the second experiment, mean furcilia size was $8.52 \mathrm{~mm}$ (FIII and FIV larvae) and the biomass was 3 times higher $\left(740 \mu \mathrm{g} \mathrm{C} \mathrm{l}^{-1}\right)$. Survival of furcilia in the experiments was good: in all but one of the bottles, at least 7 of the 8 added furcilia (2.9 ind. $\mathrm{l}^{-1}$ ) were recovered alive. Mean Oithona size was the same in the two experiments $(0.75 \mathrm{~mm}$; $t$-test: $p=0.23$ ), and did not change due to the presence or absence of furcilia ( $t$-test: $\mathrm{p}>0.15$ ). Despite the larger number of Oithona used in the second experiment (20 ind. $\mathrm{l}^{-1}$ vs. 15 ind. $\mathrm{l}^{-1}$ in the first experiment), the end biomass in the two experiments in treatments without krill was the same $\left(25.5 \mu \mathrm{g} \mathrm{C} \mathrm{l}^{-1} ; \mathrm{p}=0.62\right)$, due to differences in copepod survival between the 2 experiments $(97$ and $82 \%$ survival in treatments without furcilia in the first and second experiment, respectively; Fig. 1A,B).

\section{Grazing impact on Oithona, algae and ciliates}

While furcilia had a considerable impact on total algal biomass, their suppression of copepods, ciliates and dinoflagellates was much greater. Presence of furcilia reduced end chl a concentrations by approximately $40 \%$ in the first, and $80 \%$ in the second experiment, both significant declines ( $p<0.001$; Fig. 1C,D). In both experiments, there were marginally higher chl a concentrations in treatments with Oithona than in 
those without, but these differences were not significant $(p>0.05)$. Furcilia impact on copepods was much larger than that on chl a: in treatments with both krill and copepods, copepod end abundance was 8 and $5 \%$ of that in treatments without krill in the first and second experiments, respectively (Fig. 1C,D). The impact of furcilia on ciliates was even larger than that on copepods. At the end of both experiments, treatments with krill had less than $1 \%$ of the ciliate abundance of treatments without krill (Fig. 1E,F). Oithona had a somewhat different impact on ciliates, dependent on the experiment. In the first experiment, there was a marginal copepod main effect and a marginal krill $\times$ cope-
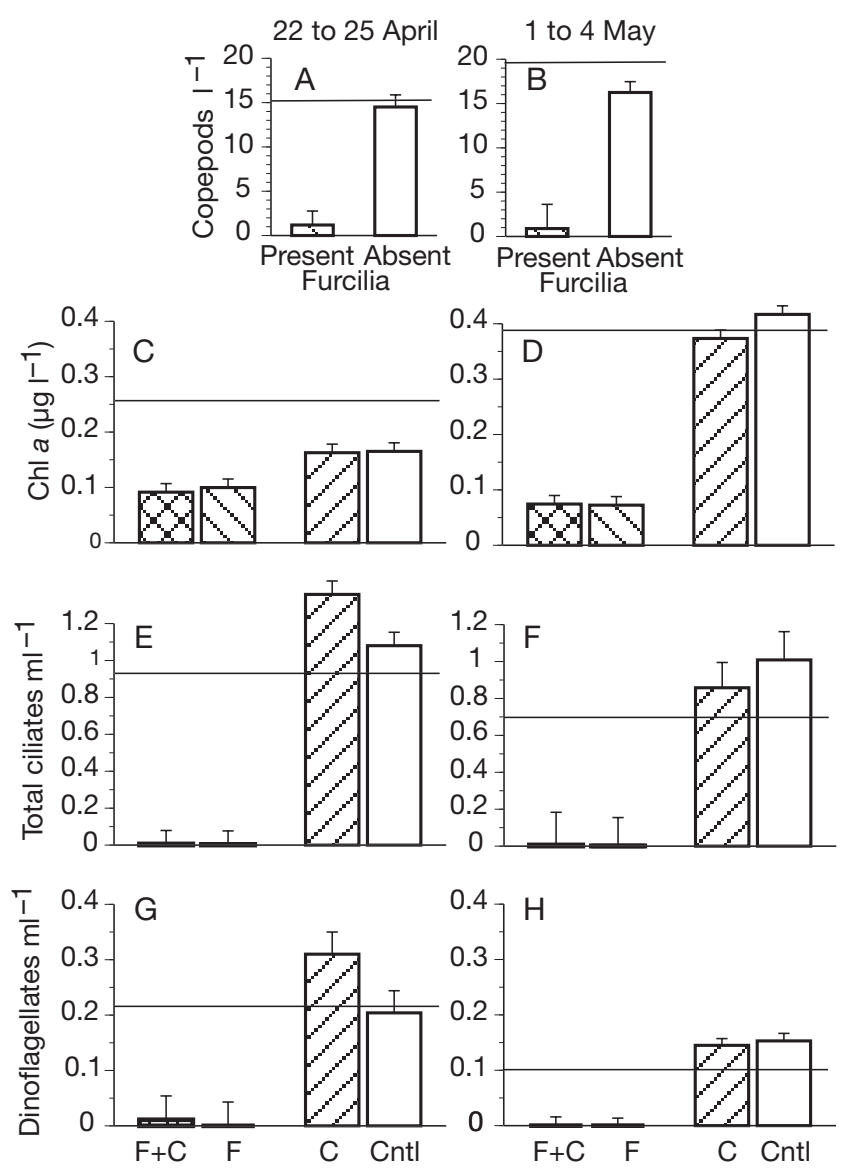

Fig. 1. Furcilia-Oithona experiments. Mean (A,B) copepod abundance, $(\mathrm{C}, \mathrm{D}) \mathrm{chl}$ a concentration, $(\mathrm{E}, \mathrm{F})$ total ciliate abundance, and $(\mathrm{G}, \mathrm{H})$ total dinoflagellate abundance. Left panels (A,C,E,G): first experiment (22 to 25 April 2001, initial Oithona abundance 15 ind. $\mathrm{l}^{-1}$, FIII furcilia abundance 2.9 ind. $\mathrm{l}^{-1}$ ). Right panels $(\mathrm{B}, \mathrm{D}, \mathrm{F}, \mathrm{H})$ ) second experiment (1 to 4 May 2001, initial Oithona abundance 20 ind. $\mathrm{l}^{-1}$, FIII and FIV furcilia abundance 2.9 ind. $\mathrm{l}^{-1}$ ). As a result of differences in furcilia stages, initial furcilia biomass in the second experiment was 3 -fold that in the first experiment. $\mathrm{F}+\mathrm{C}$ : treatments with both furcilia and copepods; F: furcilia alone; C: copepods alone; Cntl: control treatments without furcilia or copepods; horizontal lines: initial abundance; error bars: $1 \mathrm{SE}$ pod interaction ( $p=0.082$ and $p=0.086$, respectively), resulting from a trend towards higher ciliate abundance in treatments with copepods compared to those without, particularly when furcilia were not present (copepods present vs. copepods absent for treatments without furcilia: $\mathrm{p}=0.021$ in an unprotected $t$-test). In the second furcilia-Oithona experiment, which had higher initial copepod abundance, this trend was not seen (copepod main effect and copepod $\times$ krill interaction: $p>0.60$ ) (Fig. 1). The response of dinoflagellates to the experimental manipulations was similar to that of the ciliates. (Fig. 1G,H, Table 3).

Because furcilia reduced Oithona and ciliate abundances to such a great degree, the calculated grazing rates on Oithona and ciliates are certainly underestimates. Nevertheless, they provide an indication of the potential impact of furcilia on ciliates and small copepods. In the first experiment, the grazing rate of furcilia on Oithona was 5 times the grazing rate on algae, and the grazing rate on ciliates was almost 10 times higher than that on algae (Table 4). In the second experiment, with larger furcilia, grazing on algae was almost 3 times higher than that in the first experiment, but grazing on Oithona was roughly similar, and grazing on ciliates lower, than in the first experiment. As would be expected from the observed grazing rates, furcilia had strong positive electivities for ciliates, particularly in the first experiment (Table 4). Electivity for algae was always negative, whereas electivity for copepods was neutral in both experiments.

The ciliate community in our experiments was analyzed with a high taxonomic resolution. We could differentiate 28 different species and/or morphotypes, 11 of which made up at least $2 \%$ of total abundance. These were largely oligotrichs, such as Strombidium acutum, Strobilidium neptuni, Strombidium conicum, Leegaardiella ovalis and Lohmanniella oviformis. The massive grazing impact of furcilia precluded any division between grazing-vulnerable or grazing-resistant groups - all ciliate taxa were reduced to near zero abundance. In addition, no differences in their vulnerability to copepod grazing could be found, even when bottles that contained furcilia were excluded. Once these samples were excluded, there was limited statistical power remaining with which to discern differences.

\section{Grazing impact on nanoplankton and bacteria}

In stark contrast to the effect of furcilia on copepods, chl $a$ and ciliates, no significant or even nearsignificant effects on bacteria, HNAN or PNAN were found in either experiment (Fig. 2, Table 2). There 
Table 3. F- and p-values from ANOVA of the furcilia-Oithona experiments. Bacteria, HNAN and PNAN (heterotrophic and phototrophic nanoplankton, respectively) were sampled twice during experiments and data analyzed in a repeated measures ANOVA. Chl a and ciliate abundance were measured only at the end of experiments and were analyzed with 2 -way factorial ANOVA. 'Furcilia' is the furcilia presence/absence treatment, 'Oithona' is the Oithona presence/absence treatment. For both between- and within-time effects, $\mathrm{df}=1,12$

\begin{tabular}{|c|c|c|c|c|c|c|c|c|}
\hline \multirow{2}{*}{$\begin{array}{l}\text { Response } \\
\text { variable }\end{array}$} & & \multirow[b]{2}{*}{ Furcilia } & \multirow[b]{2}{*}{ Oithona } & \multirow[b]{2}{*}{$\begin{array}{c}\text { Furcilia } \times \\
\text { Oithona }\end{array}$} & \multicolumn{2}{|l|}{-Treatment } & \multirow[b]{2}{*}{$\begin{array}{l}\text { Time } \times \\
\text { Oithona }\end{array}$} & \multirow[b]{2}{*}{$\begin{array}{c}\text { Time } \times \text { Furcilia } \\
\quad \times \text { Oithona }\end{array}$} \\
\hline & & & & & Time & $\begin{array}{c}\text { Time } \times \\
\text { Furcilia }\end{array}$ & & \\
\hline \multicolumn{9}{|l|}{ Expt 1} \\
\hline \multirow[t]{2}{*}{ Chl a } & $F$ & 26.2 & 0.16 & 0.05 & & & & \\
\hline & $\mathrm{p}$ & $<0.001$ & 0.696 & 0.828 & & & & \\
\hline \multirow[t]{2}{*}{ Dinoflagellates } & $F$ & 33.70 & 1.84 & 1.21 & & & & \\
\hline & $\mathrm{p}$ & $<0.001$ & 0.208 & 0.300 & & & & \\
\hline \multirow[t]{2}{*}{ Ciliates } & $F$ & 271 & 3.62 & 3.50 & & & & \\
\hline & $\mathrm{p}$ & $<0.001$ & 0.082 & 0.086 & & & & \\
\hline \multirow[t]{2}{*}{ Bacteria } & $F$ & 0.01 & $<0.01$ & 0.90 & 4.17 & 0.03 & 0.18 & 2.58 \\
\hline & $\mathrm{p}$ & 0.942 & 0.952 & 0.362 & 0.064 & 0.864 & 0.681 & 0.134 \\
\hline \multirow[t]{2}{*}{ HNAN } & $F$ & 0.10 & 0.21 & 1.58 & 35.0 & 1.31 & 0.44 & 5.72 \\
\hline & $\mathrm{p}$ & 0.752 & 0.657 & 0.233 & $<0.001$ & 0.274 & 0.518 & 0.034 \\
\hline \multirow[t]{2}{*}{ PNAN } & $F$ & 0.09 & 0.84 & 0.01 & 6.79 & 0.56 & 1.90 & 0.01 \\
\hline & $\mathrm{p}$ & 0.774 & 0.379 & 0.916 & 0.023 & 0.467 & 0.193 & 0.934 \\
\hline \multicolumn{9}{|l|}{ Expt 2} \\
\hline \multirow{2}{*}{ Chl a } & $F$ & 334 & 1.39 & 1.67 & & & & \\
\hline & $\mathrm{p}$ & $<0.001$ & 0.646 & 0.193 & & & & \\
\hline \multirow[t]{2}{*}{ Dinoflagellates } & $F$ & 115.1 & 0.076 & 0.076 & & & & \\
\hline & $\mathrm{p}$ & $<0.001$ & 0.787 & 0.787 & & & & \\
\hline \multirow[t]{2}{*}{ Ciliates } & $F$ & 35.7 & 0.22 & 0.25 & & & & \\
\hline & $\mathrm{p}$ & $<0.001$ & 0.607 & 0.574 & & & & \\
\hline \multirow[t]{2}{*}{ Bacteria } & $F$ & 0.56 & 0.99 & 2.13 & 15.93 & 0.05 & 3.43 & $<0.01$ \\
\hline & $\mathrm{p}$ & 0.470 & 0.339 & 0.170 & 0.002 & 0.827 & 0.089 & 0.991 \\
\hline \multirow[t]{2}{*}{ HNAN } & $F$ & 0.20 & 0.66 & 1.74 & $<0.01$ & 2.59 & 0.43 & 0.66 \\
\hline & $\mathrm{p}$ & 0.665 & 0.431 & 0.212 & 0.993 & 0.134 & 0.527 & 0.433 \\
\hline \multirow[t]{2}{*}{ PNAN } & $F$ & 0.66 & 2.85 & 1.13 & 41.55 & 0.09 & 2.34 & 0.14 \\
\hline & $\mathrm{p}$ & 0.432 & 0.117 & 0.308 & $<0.001$ & 0.774 & 0.152 & 0.717 \\
\hline
\end{tabular}

Table 4. Clearance rates and electivities of furcilia larvae, Oithona and Metridia. Clearance rate is scaled to predator abundance $\left(\mathrm{ml}\right.$ ind $.^{-1} \mathrm{~d}^{-1}, \pm 1 \mathrm{SE}$ ). Grazing rates given only when they differed significantly from 0 . In the second furcilia-Oithona experiment, Oithona was present at the end of only 1 treatment; therefore, no SD could be calculated. Electivity was calculated from Chesson's $\alpha$, scaled so that 0 is neutral selection (grazing in proportion to relative abundance in the environment). For the group of grazing-vulnerable ciliates, electivity was calculated with ciliates split into grazing-vulnerable and -resistant groups

\begin{tabular}{|c|c|c|c|c|c|c|c|c|}
\hline \multirow[t]{2}{*}{ Expt } & \multicolumn{4}{|c|}{ _ Clearance rate- } & \multirow{2}{*}{$\mathrm{Chla}$} & \multicolumn{2}{|c|}{ Electivity_- } & \multirow[b]{2}{*}{$\begin{array}{l}\text { Vulnerable } \\
\text { ciliates }\end{array}$} \\
\hline & Chl a & Oithona & $\begin{array}{c}\text { Total } \\
\text { ciliates }\end{array}$ & $\begin{array}{c}\text { Vulnerable } \\
\text { ciliates }\end{array}$ & & Oithona & $\begin{array}{c}\text { Total } \\
\text { ciliates }\end{array}$ & \\
\hline Furcilia-Oithona I & $78.5 \pm 11$ & $383 \pm 24$ & $768 \pm 61$ & - & -0.78 & 0.03 & 0.71 & - \\
\hline Furcilia-Oithona II & $215 \pm 13$ & 354 & $624 \pm 45$ & - & -0.48 & -0.04 & 0.48 & - \\
\hline Metridia-Oithona & - & $202 \pm 48$ & $139 \pm 26$ & $325 \pm 50$ & -1 & 0.56 & 0.05 & 0.52 \\
\hline Oithona grazing & - & - & - & $9.67 \pm 3.2$ & -1.0 & - & - & 1.0 \\
\hline
\end{tabular}

were also no time-dependent interactions (except for 1 time $\times$ krill $\times$ copepod interaction for HNAN in the first experiment), indicating that the duration of the experiments did not affect their outcome. In the 1 significant time-dependent effect, HNAN abundance was higher in treatments with furcilia or copepods than in the control treatments, but this effect was only seen at the end of the first experiment (Fig. 2C). PNAN increased between the first and second sampling occasions in both experiments (Fig. 2E,F), a trend also observed for the HNAN of the first experiment (Fig. 2C). 


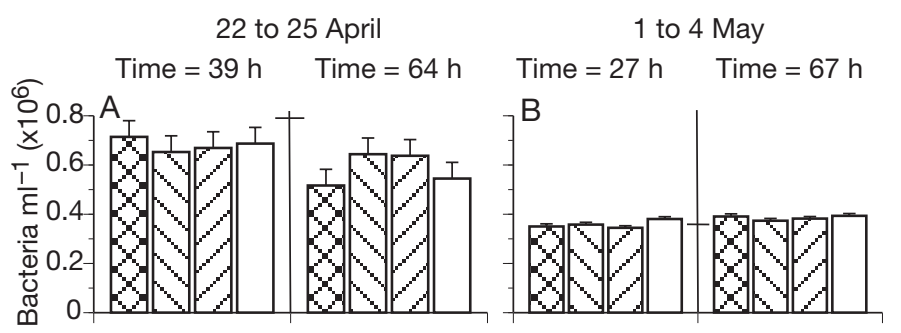

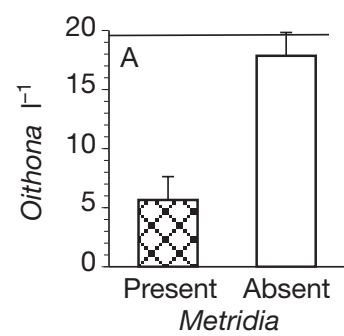
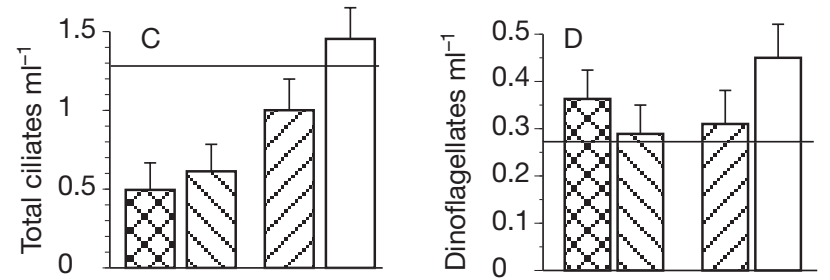
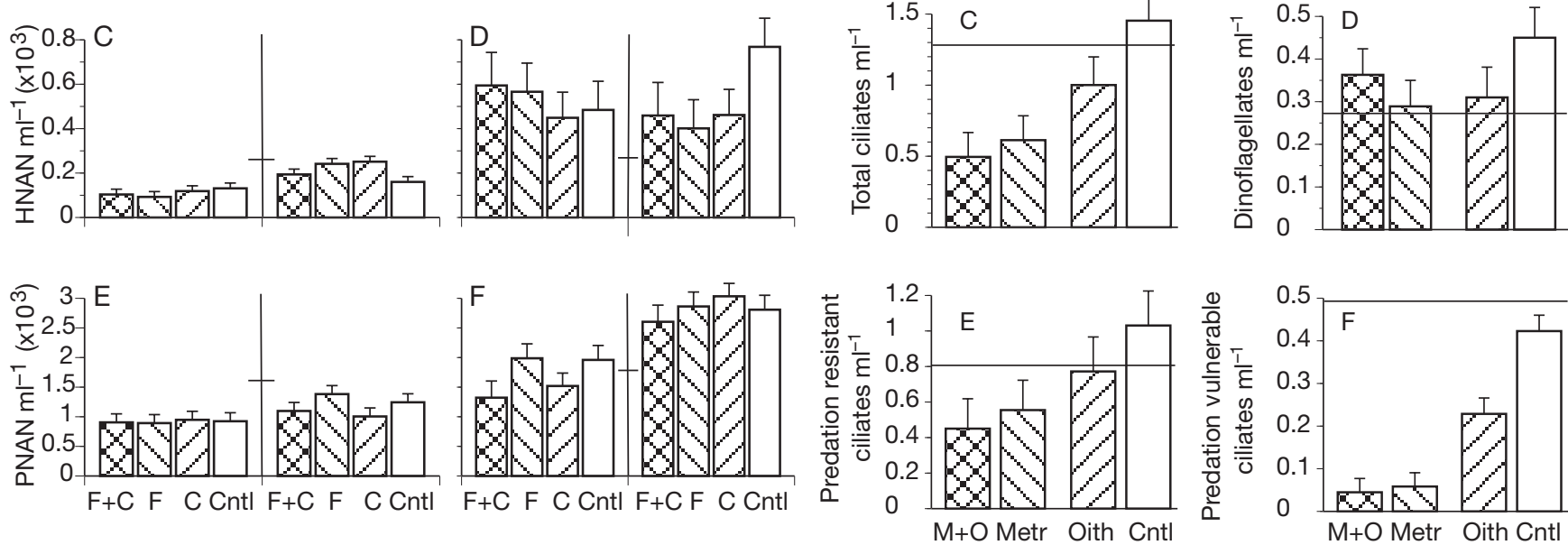

Fig. 2. Furcilia-Oithona experiments. Mean abundance of (A,B) bacteria, (C,D) heterotrophic nanoplankton (HNAN) and $(\mathrm{E}, \mathrm{F})$ phototrophic nanoplankton (PNAN). Left panels (A,C,E): first experiment (22 to 25 April 2001). Right panels (B,D,F): second experiment (1 to 4 May 2001). Initial abundance (horizontal lines), mid-point abundance (39 or $27 \mathrm{~h}$ ) and end abundance (64 or $67 \mathrm{~h}$ ) shown. Copepod and furcilia

treatment abbreviations as in Fig. 1. Error bars: $1 \mathrm{SE}$

Fig. 3. Metridia-Oithona experiment. Mean (A) end copepod abundance, (B) chl a concentration, (C) total ciliates, (D) dinoflagellates, (E) grazing-resistant ciliates and (F) grazing-vulnerable ciliates. M+O: treatments with both Metridia and Oithona; Metr: Metridia alone; Oith: Oithona alone; Cntl: Control treatments without Metridia or Oithona; horizontal lines: initial abundance; error bars: $1 \mathrm{SE}$

Table 5. F- and p-values from ANOVA of the Metridia-Oithona experiment. Bacteria, HNAN and PNAN (heterotrophic and phototrophic nanoplankton, respectively) were sampled twice during experiments and data analyzed in a repeated-measures ANOVA. Chl $a$ and ciliate abundance were measured only at the end of experiments and were analyzed with 2-way factorial ANOVA. For both between- and within-time effects, df $=1,12$

\begin{tabular}{|c|c|c|c|c|c|c|c|c|}
\hline \multirow{2}{*}{$\begin{array}{l}\text { Response } \\
\text { variable }\end{array}$} & & \multirow[b]{2}{*}{ Metridia } & \multirow[b]{2}{*}{ Oithona } & \multirow[b]{2}{*}{$\begin{array}{c}\text { Metridia } \times \\
\text { Oithona }\end{array}$} & \multirow{2}{*}{$\begin{array}{l}\text {-Treatment } \\
\text { Time }\end{array}$} & \multirow[b]{2}{*}{$\begin{array}{c}\text { Time } \times \\
\text { Metridia }\end{array}$} & \multirow[b]{2}{*}{$\begin{array}{l}\text { Time } \times \\
\text { Oithona }\end{array}$} & \multirow[b]{2}{*}{$\begin{array}{c}\text { Time } \times \text { Metridia } \\
\times \text { Oithona }\end{array}$} \\
\hline & & & & & & & & \\
\hline \multirow[t]{2}{*}{ Chl a } & $F$ & 1.49 & 0.47 & 2.54 & & & & \\
\hline & $\mathrm{p}$ & 0.250 & 0.510 & 0.142 & & & & \\
\hline \multirow[t]{2}{*}{ Dinoflagellates } & $F$ & 0.60 & 0.23 & 2.41 & & & & \\
\hline & $\mathrm{p}$ & 0.457 & 0.642 & 0.155 & & & & \\
\hline \multirow[t]{2}{*}{ Total ciliates } & $F$ & 13.22 & 2.37 & 0.82 & & & & \\
\hline & $\mathrm{p}$ & 0.005 & 0.154 & 0.387 & & & & \\
\hline \multirow{2}{*}{$\begin{array}{l}\text { Vulnerable } \\
\text { ciliates }\end{array}$} & $F$ & 61.70 & 8.85 & 6.70 & & & & \\
\hline & $\mathrm{p}$ & $<0.001$ & 0.014 & 0.027 & & & & \\
\hline \multirow{2}{*}{$\begin{array}{l}\text { Resistant } \\
\text { ciliates }\end{array}$} & $F$ & 4.83 & 1.00 & 0.18 & & & & \\
\hline & $\mathrm{p}$ & 0.053 & 0.341 & 0.698 & & & & \\
\hline \multirow[t]{2}{*}{ Bacteria } & $F$ & 0.95 & 2.93 & 2.69 & 20.16 & 0.04 & 2.03 & 0.41 \\
\hline & $\mathrm{p}$ & 0.352 & 0.118 & 0.132 & 0.001 & 0.847 & 0.185 & 0.535 \\
\hline \multirow[t]{2}{*}{ HNAN } & $F$ & 1.22 & 0.57 & 0.16 & 0.59 & 1.61 & 0.05 & 0.80 \\
\hline & $\mathrm{p}$ & 0.296 & 0.469 & 0.696 & 0.459 & 0.233 & 0.831 & 0.393 \\
\hline \multirow[t]{2}{*}{ PNAN } & $F$ & 2.50 & 0.27 & 0.02 & 3.78 & 0.16 & 0.04 & 0.03 \\
\hline & $\mathrm{p}$ & 0.145 & 0.614 & 0.884 & 0.080 & 0.700 & 0.838 & 0.874 \\
\hline
\end{tabular}




\section{Metridia-Oithona experiment}

$$
\text { Experimental conditions }
$$

The Metridia-Oithona experiment had the lowest initial chl $a$, PNAN and HNAN concentrations, but the highest ciliate abundance of the 4 experiments (Table 2). Mean temperature during the experiment was $0.95^{\circ} \mathrm{C}$. Both Metridia and Oithona survival was good. With the exception of 1 bottle (which was excluded from the analysis), $75 \%$ of the Metridia and, in treatments without Metridia, $90 \%$ of the Oithona were recovered at the end of the experiment. Mean length of Metridia was $2.98 \mathrm{~mm}$, and total Metridia biomass at

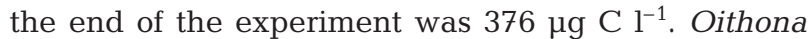
biomass was $43 \mu \mathrm{g} \mathrm{Cl}^{-1}$ in treatments without Metridia.

Grazing impact on Oithona, algae and ciliates

The presence of Metridia reduced the abundance of Oithona by approximately two-thirds $(\mathrm{p}=0.01$; Fig. 3A), but did not alter Oithona mean size ( $p>0.1)$. Although chl a declined over the course of the experiment, this was independent of the Metridia and Oithona treatments (Fig. 3B, Table 5). A total of 34 ciliate species were found, but only 10 species were abundant enough to contribute to at least $2 \%$ of total abundance in any one treatment. Total ciliate and dinoflagellate abundance in the control treatments increased moderately over the course of the experiment. In Metridia treatments, ciliate abundance was reduced to approximately one-third of the control values (Fig. 3C, Table 5). Neither the apparent decline in ciliate abundance in the presence of Oithona nor the Metridia-Oithona interaction was significant. Dinoflagellate abundance was low and did not respond to either the Metridia or Oithona manipulations (Fig. 3D, Table 5). The cluster analysis (using species comprising $\leq 2 \%$ total abundance in any treatment) separated ciliates into groups either relatively resistant or vulnerable to grazing. The grazing-resistant group made up two-thirds of total ciliate abundance and consisted of 10 species: 5 oligotrichs (sensu lato), 2 prostome species, the haptorids Lacrymaria sp. and Mesodinium pupula, the phyllopharynid Gymnozoum vivparum and a peritrich. There was a non-significant trend towards lower ciliate abundance in treatments where Metridia were present, and no significant reduction due to the presence of Oithona (Fig. 3E, Table 5). The grazing-vulnerable group was made up of Lohmanniella oviformis, 3 other oligotrich species 20 to $45 \mu \mathrm{m}$ in length, and a large Lacrymaria sp. that was $145 \mu \mathrm{m}$ in length. These ciliates were strongly suppressed by Metridia, with an end abundance of only ca. $15 \%$ of
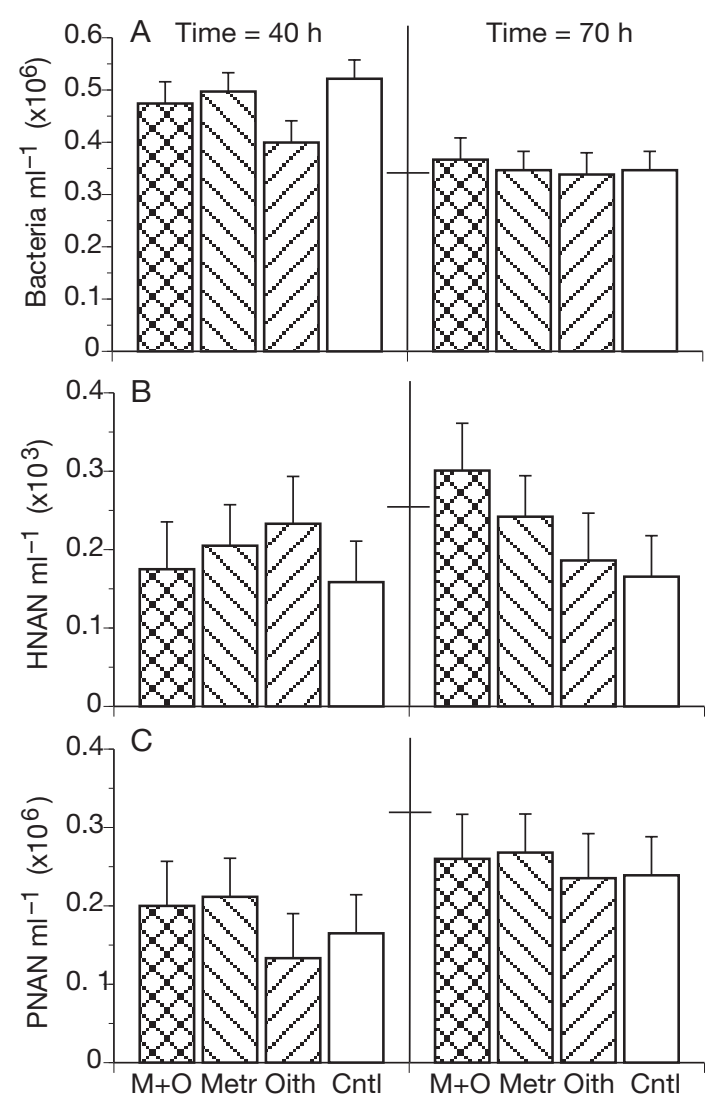

Fig. 4. Metridia-Oithona experiment. Mean abundance of (A) bacteria, (B) heterotrophic nanoplankton (HNAN) and (C) phototrophic nanoplankton (PNAN). Initial abundance (horizontal lines), mid-point abundance $(40 \mathrm{~h})$, and end abundance $(70 \mathrm{~h})$ shown. Metridia and Oithona treatment abbreviations as in Fig. 3. Error bars: 1 SE

the ciliate abundance in treatments without Metridia. The effect of Oithona on ciliates was more moderate, but also reduced grazing-vulnerable ciliate abundance by approximately $40 \%$. There was also an interaction between the effects of Metridia and Oithona, with the Oithona effect (along with much of the Oithona) disappearing in the presence of Metridia (Fig. 3F).

\section{Grazing impact on nanoplankton and bacteria}

As in the furcilia-Oithona experiments, manipulations at higher trophic levels did not affect flagellates or bacteria. HNAN, PNAN and bacteria were all unaffected by the presence/absence of Metridia and Oithona (Fig. 4, Table 5). Time-dependent effects were mostly absent, and only bacterial abundance varied between the 2 sampling occasions. End abundances of bacteria, HNAN and PNAN were similar to the initial abundances (Fig. 4). 

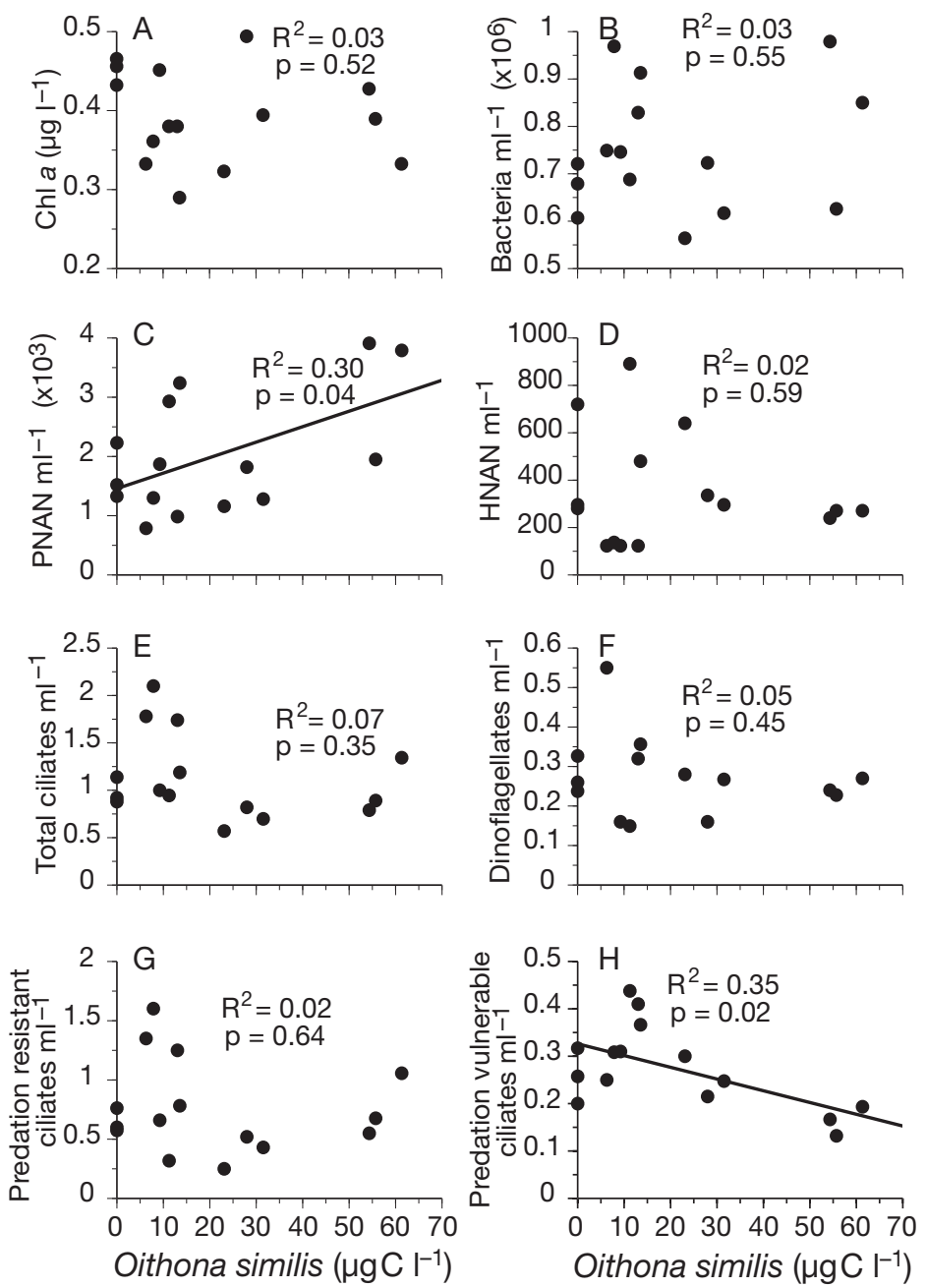

Fig. 5. Oithona grazing experiment. End values for (A) chl a concentration, and abundances of (B) bacteria, (C) phototrophic nanoplankton (PNAN), (D) heterotrophic nanoplankton (HNAN), (E) total ciliates, (F) dinoflagellates, (G) grazingresistant ciliates and $(\mathrm{H})$ grazing-vulnerable ciliates. Regression lines given only when slope differed significantly from zero

\section{Oithona experiment}

\section{Experimental conditions}

This experiment was run with water from $10 \mathrm{~m}$ depth from a shelf station (Table 1), with an average incubation water temperature of $1.1^{\circ} \mathrm{C}$. Initial chl a concentration was $0.35 \mathrm{\mu g}^{-1}$, and flagellate, bacterial and ciliate abundances were proportionately low (Table 2). Copepod survival was good, with no difference in copepod biomass from beginning to end of the experiment ( $\mathrm{p}=$ 0.11). Oithona biomass in treatments with copepods ranged from $7.8 \mu \mathrm{C} \mathrm{C} \mathrm{l}^{-1}$ in the 4 ind. $\mathrm{l}^{-1}$ treatment to $57 \mu \mathrm{C} \mathrm{C}^{-1}$ in the 32 ind. $\mathrm{l}^{-1}$ treatment (mean size: $0.79 \mathrm{~mm})$.

\section{Grazing impact on the plankton community}

The effect of Oithona on the plankton community was weaker than that recorded for furcilia and Metridia. Mean chl a concentration at the end of the experiment was $0.39 \mu \mathrm{g} \mathrm{l^{-1 }}$, with no relationship observed between chl $a$ and end copepod biomass $\left(\mathrm{R}^{2}=0.03, \mathrm{p}=0.56\right.$; Fig. 5A). Mean bacterial and HNAN abundances at the end of the experiment were $0.75 \times 10^{6}$ and $2.01 \times 10^{3}$ cells $\mathrm{ml}^{-1}$, respectively. Similar to chl $a$, there was no significant regression with copepod biomass ( $p>0.50$; Fig. 5B,D). However, a weak positive relationship between copepod biomass and PNAN abundance was present $\left(\mathrm{R}^{2}=0.30, \mathrm{p}=\right.$ 0.036). In the absence of copepods PNAN abundance was $1.46 \times 10^{3}$ cells $\mathrm{ml}^{-1}$, increasing by approximately $100 \%$ in the treatment containing the highest concentration of copepods (Fig. 5C).

A total of 33 ciliate species were found in samples at the end of the experiment, 12 of these contributing at least $2 \%$ to total abundance. These were mostly oligotrichs (sensu lato), with 2 litostome and 1 prostome species. Final mean ciliate abundance in treatments without Oithona was 0.98 cells $\mathrm{ml}^{-1}$, a nonsignificant increase $(p=0.24)$ from the initial abundance of 0.74 cells $\mathrm{ml}^{-1}$. Total ciliate abundance did not vary with Oithona biomass ( $p=0.35$; Fig. 5E). However, the cluster analysis split the ciliates into 2 groups: one of which made up approximately twothirds of the total ciliate abundance and was grazingresistant (regression against copepod biomass: p = 0.64), and a grazing-vulnerable group that did decline with increasing copepod biomass $\left(\mathrm{R}^{2}=0.35\right.$, $\mathrm{p}=0.02 ;$ Fig. 5G,H). The grazing-vulnerable group consisted of 2 small oligotrichs Lohmanniella oviformis and Cyrtostrombidium sp., and the litostome Mesodinium pupula, all approximately $20 \mu \mathrm{m}$ in diameter. Among the grazing-vulnerable group, the end ciliate abundance at the highest copepod density (32 ind. $\mathrm{l}^{-1}, 57 \mu \mathrm{g} \mathrm{C} \mathrm{l}^{-1}$ ) was reduced to ca. $55 \%$ of that in the copepod-free treatments (Fig. 5H). The response of total dinoflagellate abundance was similar to that of total ciliates, in that there was no significant decline with increasing Oithona abundance (Fig. 5F). However, dinoflagellate abundance was too low to distinguish between potentially grazingvulnerable or grazing-resistant groups (initial abundance: 0.13 cells $\mathrm{ml}^{-1}$ ).

Clearance rates were only calculated for the grazingvulnerable ciliates, as these were the only group to significantly decline with increasing Oithona abundance. This produced a grazing rate of $9.67 \mathrm{ml}$ ind. ${ }^{-1} \mathrm{~d}^{-1}\left(\mathrm{R}^{2}=\right.$ $0.42, \mathrm{p}=0.009$ ). Because there was no significant grazing on algal chl $a$, the electivity of Oithona was +1 for vulnerable ciliates and -1 for chl a (Table 4). 


\section{DISCUSSION}

These experiments demonstrated that heterotrophic food sources make up a substantial proportion of the diet of furcilia, with strong positive selection for ciliates over algae. Grazing vulnerability of the ciliates was only species-specific when copepods, not furcilia, were the predators. There was a large range of impacts on ciliates, from minimal, selective predation by Oithona, through moderate selective predation by Metridia, to massive and unselective predation by furcilia. Despite this broad spectrum of predation pressures, in only one case (PNAN in the Oithona experiment) was there any response in the trophic levels beneath ciliates. There was no interaction between the grazing effects of Oithona and furcilia, due to the large direct grazing impact of furcilia on ciliates. In contrast, Metridia grazing on Oithona reduced grazing pressure on grazing-vulnerable ciliates. The impact of Oithona was minimal, but some selectivity among ciliate prey could be shown.

\section{Grazing impact of krill larvae and copepods, importance of ciliate community composition}

Both adult and larval krill are known herbivores, as demonstrated by the furcilia in these experiments. The differences in end chl a concentrations between treatments with and without furcilia resulted in grazing rates within the range previously observed for FIII larvae grazing on a mixed algal community at a similar time of year (Table 4; Meyer et al. 2002). However, it is also known that adult krill are not pure herbivores, and that heterotrophic food sources may make up a substantial proportion of krill's diet (Granéli et al. 1993, Atkinson \& Snÿder 1997, Perissinotto et al. 2000). There has been considerably less research carried out on larval krill, but here too, grazing on heterotrophs has been shown. Both Quetin et al. (1994) and Meyer et al. (2002) showed furcilia to be capable of grazing heterotrophs, but concluded that they were primarily herbivorous, and Meyer et al. (2002) found FIII larvae to be unselective. In contrast, the FIII-FIV larvae used in our experiments exhibited strong positive selection for ciliates. The presence or absence of Oithona did not affect the impact of furcilia on ciliates, indicating that, at least with the intense grazing pressure seen in our experiments, furcilia did not switch to or from ciliates depending on the availability of copepod prey.

Metridia also showed a clear preference for heterotrophic over phototrophic prey, with positive selection for Oithona and a subset of the ciliate community over algae. The significant interaction between the effects of Metridia and Oithona on grazing-vulnerable ciliates implies that Metridia switched between ciliate and cyclopoid prey, with a greater reduction in grazingvulnerable ciliate abundance when Oithona was absent than when it was present (Fig. 3). However, at least part of this interaction was due to grazingvulnerable ciliates also being vulnerable to Oithona predation. This was reduced in the presence of Metridia, because Metridia also consumed Oithona.

A possible reason why selective feeding by furcilia was seen in these experiments, but not in those of previous research (Atkinson \& Snÿder 1997, Meyer et al. 2002), is that ciliates were relatively more abundant in our experiments. The range of chl a concentrations at the start of our experiments was similar to that in previous studies involving furcilia and ciliates, but ciliate abundance was higher. Ciliates comprised between 0.3 and $7.6 \%$ of total particulate organic matter in Meyer et al.'s (2002) study, whereas ciliate carbon represented approximately $10 \%$ of algal carbon (admittedly a subset of total POC) at the beginning of the furcilia-Oithona and Oithona grazing experiments (and $45 \%$ of algal carbon in the Metridia-Oithona experiment). Thus, there may be a threshold minimum algal concentration or relative ciliate abundance that determines whether furcilia feed selectively. The low algal and high ciliate abundance seen in our experiments represent conditions likely to be a common feature of the Antarctic fall. The peak in ciliate biomass is broader than that for chl a, extending until the end of May (Leakey et al. 1994).

The magnitude of the impact of furcilia on ciliates and Oithona is emphasized by the fact that the clearance rates measured in our experiments are clearly underestimates. Furcilia entirely depleted ciliate and copepod prey in several of the bottles, and drove the abundance in the remainder to near zero. As a result, the same amount of grazing could have been measured in an experiment of shorter duration. The duration and predator densities used in our experiments were chosen as an estimate of what would be sufficient to see a difference not only in the prey, but also in lower trophic levels, should a trophic cascade be operating. In terms of assessing the grazing impact on algae, we achieved our aims. However, if the duration of experiments had been shorter, or fewer furcilia per bottle were used, then the calculated grazing rates on ciliates and Oithona would have been higher and the positive selection of these prey organisms over algae would have been even greater. Neither the Metrida nor the Oithona experiments showed such extreme declines in prey densities; therefore, the grazing rates measured in these experiments are not likely to be underestimates.

The limited impact of Oithona on ciliates was unexpected, as it has been shown to be an effective cili- 
ate predator and to positively select for ciliates over similar-sized diatoms or dinoflagellates (Atkinson 1996, Nakamura \& Turner 1997, Lonsdale et al. 2000). Oithona is also known to reproduce in the Antarctic fall, implying a need to feed during the time of our study (Fransz \& Gonzalez 1995). The condition of the copepods at the beginning of the experiments was good: both individuals with fat globules and females with egg masses were observed. Copepod survival in the experiments was also good, making experimental artifacts an unlikely explanation. In contrast to most other studies, we investigated the ciliate community with a high enough taxonomic resolution to discern grazing effects on individual taxa. The rate we measured for Oithona's grazing on vulnerable ciliates (Table 5) was similar to that measured previously for total ciliates by both Atikinson (1996) and Nakamura \& Turner (1997), but only a third of that measured by Lonsdale et al. (2000). In our experiment, the grazingvulnerable ciliates were small (maximum dimension $\leq 21 \mu \mathrm{m})$, and larger ciliates common in our experiments such as Strombidium acutum and Leegaardiella ovalis were not grazed, running counter to a previously reported trend of increasing vulnerability with increasing size (Nakamura \& Turner 1997). Nevertheless, the group of grazing-vulnerable ciliates were close in size to those that Atkinson (1996) found to be preferred prey of Oithona. The small size of the grazing-vulnerable ciliates and the low grazing rates by Oithona led to an estimated ingestion rate that is approximately $1 \%$ of Oithona body carbon per day. This is not only well beneath their metabolic needs, but also much less than that found by Lonsdale et al. (2000), who observed that summer populations of Oithona spp. in the Ross Sea ingested on average $90 \%$ of their body carbon per day. In 3 of the 4 experiments in Lonsdale et al.'s (2000) study, ciliate abundance was almost an order of magnitude higher than in ours. Why Oithona restricted itself to a small subset of the available prey in our study is not clear.

\section{Connection between the classic and microbial food web}

During winter and early spring, Antarctic waters are net heterotrophic, with bacterial biomass and secondary production exceeding algal biomass and primary production (Rivkin 1991). Grazing on ciliates is then a possible route to channel microbial production to krill at times when primary production is minimal. In our experiments, however, ciliates did not serve as a part of a trophic cascade by transferring changes from higher trophic levels to the microbial food web. An unintended outcome of furcilia driving ciliate abun- dance so low was that an entire trophic level — which supposedly links the microbial and classic food webs was eliminated. If ciliates were exerting top-down control on flagellates or bacteria, then ciliate removal could be expected to result in an increase at the next, lower trophic level. Quite unequivocally, this did not occur (Figs. 1 \& 2, Table 3).

Within-treatment variation was low, suggesting that there was power enough to detect real differences, had they been present. There was considerable variation in initial conditions (Table 2), suggesting that the lack of a trophic cascade from higher trophic levels to the microbial food web could be a general phenomena for the time of year within which experiments were carried out. Supporting this conclusion, recent work in the Bellinghausen Sea found bacterivory to be only slightly reduced when microzooplankton were removed (thus supposedly releasing bacterivous HNAN from predation pressure), and the presence or absence of microzooplankton had little impact on either HNAN or bacterial abundance (Vaque et al. 2004). Top-down control of Antarctic microbial communities has been previously demonstrated, but this was during summer, with a microzooplankton community dominated by dinoflagellates that were largely absent from our experiments (Kuparinen \& Bjørnsen 1992). A likely reason for the lack of top-down control in our experiments is that flagellates and bacteria were so resourcelimited that they could not grow faster when grazers were removed. Resource limitation of bacteria in the Southern Ocean has been found even during the spring bloom and austral summer, and was cited as the reason why bacterial and primary production were uncoupled in the Gerlache Strait during spring, despite remarkably low $(\leq 100)$ bacteria:HNAN ratios (Bird \& Karl 1999). Whether this is also the case during the austral autumn is unclear, due to a lack of data. The results of our experiments indicate that although ciliates may transfer microbial biomass to higher trophic levels, changes in higher trophic levels do not necessarily transfer down to the microbial food web.

Part of the explanation as to why the removal of ciliates did not change HNAN, PNAN or bacterial abundance is that ciliates do not occupy a single trophic level. The species present in our experiments could graze on both HNAN and their bacterial prey, an argument also used by Vaque et al. (2004) to account for the lack of a measurable trophic cascade in their study. In addition, predacious species such as Lacrymaria sp. and Litonotus sp. were common in our experiments. Thus, when furcilia grazed down ciliate abundance, they simultaneously removed predators on ciliates, HNAN and bacteria. When complex ciliate communities are present, it is clearly overly simplistic to expect a trophic cascade to be easily observed. 
While ciliates may have not been effective in channelling microbial production to copepods and krill, they provided indirect means of accessing algal production that would not have been otherwise available. It has been suggested that microzooplankton are generally the major grazers of phytoplankton in the ocean, and that in polar regions they consume on average $60 \%$ of primary production and $20 \%$ of algal standing stock per day (Calbet \& Landry 2004). These rates are clearly dependent on season as well as on the composition of the algal and microzooplankton community. Antarctic microzooplankton, dominated by ciliates and dinoflagellates, can graze in excess of $100 \%$ of algal production in the marginal ice zone during late spring and early summer (Burkill et al. 1995). However, Froneman \& Perissinotto (1996), working in late summer, found that microzooplankton grazed only 8 to $33 \%$ of primary production as algae were dominated by net plankton, and Caron et al. (2000) found minimal microzooplankton herbivory at 4 different times of year. The naked oligotrichs (sensu lato) that dominated the ciliate community during our experiments are largely grazers in the nanoplankton size range, with the smaller species capable of grazing smaller nanoplankton and the larger picoplankton size classes (Jonsson 1986, Kivi \& Setälä 1995). These algal size classes are beneath the size range that can be effectively grazed by krill. But by grazing ciliates, krill would have access to at least part of the production from these size classes. However, whether ciliates are for furcilia primarily a method to access algal production from size classes too small to graze directly, or under different circumstances and times of year a route to microbial production, remains to be demonstrated.

Acknowledgements. We thank Captian U. Pahl and the crew of RV 'Polarstern' for their help and support during ANTXVIII $5 \mathrm{~b}$, and cruise leader U. Bathmann for the smooth running of the cruise. We also thank A. Atkinson and S. Schiel for assistance with copepod and krill identification, T. Hansen and S. Zitzmann for chlorophyll determination, M. ClaessensKenning for ciliate counts and T. Burgmer for zooplankton counts. This work was supported by Deutsche Forschungsgemeinschaft grants WI 1623/2 to S.A.W. and BE 2279/4 to U.G.B.

\section{LITERATURE CITED}

Atkinson A (1996) Subantarctic copepods in an oceanic, low chlorophyll environment: ciliate predation, food selectivity and impact on prey populations. Mar Ecol Prog Ser 130: 85-96

Atkinson A (1998) Life cycle strategies of epipelagic copepods in the Southern Ocean. J Mar Sys 15:289-311

Atkinson A, Snÿder R (1997) Krill-copepod interactions at South Georgia, Antarctica, I. Omnivory by Euphausia superba. Mar Ecol Prog Ser 160:63-76

Bird DF, Karl DM (1999) Uncoupling of bacteria and phytoplankton during the austral spring bloom in Gerlache Strait, Antarctic Peninsula. Aquat Microb Ecol 19:13-27

Burkill PH, Edwards ES, Sleigh MA (1995) Microzooplankton and their role in controlling phytoplankton growth in the marginal ice zone of the Bellingshausen Sea. Deep-Sea Res II 42:1277-1290

Calbet A, Landry MR (2004) Phytoplankton growth, microzooplankton grazing, and carbon cycling in marine systems. Limnol Oceanogr 49:51-57

Caron DA, Dennett MR, Lonsdale DJ, Moran DM, Shalapyonok L (2000) Microzooplankton herbivory in the Ross Sea, Antarctica. Deep-Sea Res II 47:3249-3272

Chesson J (1983) The estimation and analysis of preference and its relationship to foraging models. Ecology 64: $1297-1304$

Daly KL (1990) Overwintering development, growth, and feeding of larval Euphausia superba in the Antarctic marginal ice zone. Limnol Oceanogr 35:1564-1576

Daly KL (2004) Overwintering growth and development of larval Euphausia superba: an interannual comparison under varying environmental conditions west of the Antarctic Peninsula. Deep-Sea Res II 51:2139-2168

Fransz HG, Gonzalez SR (1995) The production of Oithona similis (Copepoda: Cyclopoida) in the Southern Ocean. ICES J Mar Sci 52:549-555

Fransz HG, Gonzalez SR (1997) Latitudinal metazoan plankton zones in the Antarctic Circumpolar Current along 6 degrees W during austral spring 1992. Deep-Sea Res II 44:395-414

Froneman PW, Perissinotto R (1996) Structure and grazing of the microzooplankton communities of the Subtropical Convergence and a warm-core eddy in the Atlantic sector of the Southern Ocean. Mar Ecol Prog Ser 135:237-245

Froneman PW, Pakhomov EA, Perissinotto R, McQuaid CD (1996) Role of microplankton in the diet and daily ration of Antarctic zooplankton species during austral summer. Mar Ecol Prog Ser 143:15-23

Frost BW (1972) Effects of size and concentration of food particles on the feeding behavior of the marine planktonic copepod Calanus pacificus. Limnol Oceanogr 17:805-815

Garrison DL, Buck KR, Gowing MM (1993) Winter plankton assemblage in the ice edge zone of the Weddell and Scotia Seas: composition, biomass and spatial distributions. Deep-Sea Res I 40:311-338

Granéli E, Granéli W, Rabanni MM, Daugbjerg N, Fransz G, Cuzin-Roudy J, Alder VA (1993) The influence of copepod and krill grazing on the species composition of phytoplankton communities from the Scotia-Weddell sea. Polar Biol 13:210-213

Jonsson PR (1986) Particle size selection, feeding rates and growth dynamics of marine planktonic oligotrichous ciliates (Ciliophora: Oligotrichina). Mar Ecol Prog Ser 33: $265-277$

Kahl A (1930-1935) Urtiere oder Protozoa: I: Wimpertiere oder Ciliata (Infusoria), eine Bearbeitung der freilebenden und ectocomensalen Infusorien der Erde, unter Ausschluß der marinen Tintinnidae. In: Dahl F (ed) Die Tierwelt Deutchlands, Vol 18, 20, 21, 25. G. Fischer, Jena, p 1-886

Kivi K, Setälä O (1995) Simultaneous measurement of food particle selection and clearance rates of planktonic oligotrich ciliates (Ciliophora: Oligotrichina). Mar Ecol Prog Ser 119:125-137

Kuparinen J, Bjørnsen PK (1992) Bottom-up and top-down controls of the microbial food web in the Southern Ocean: experiments with manipulated microcosms. Polar Biol 12: 198-195 
Leakey R, Fenton N, Clarke A (1994) The annual cycle of planktonic ciliates in nearshore waters at Signy Island, Antarctica. J Plankton Res 16:841-856

Lehman JT, Sandgren CD (1985) Species-specific rates of growth and grazing loss among freshwater algae. Limnol Oceanogr 30:34-46

Lonsdale DJ, Caron DA, Dennett MR, Schaffner R (2000) Predation by Oithona spp. on protozooplankton in the Ross Sea, Antarctica. Deep-Sea Res II 47:3273-3283

Lynn DH, Montagnes DJS (1988a) Taxonomic descriptions of some conspicuous species in the Family Strombidiidae (Ciliophora: Oligotrichida) from the Isles of Shoals, Gulf of Maine. J Mar Biol Assoc UK 68:259-276

Lynn DH, Montagnes DJS (1988b) Taxonomic descriptions of some conspicuous species of strobilidiine ciliates (Ciliophora: Choreotrichida) from the Isles of Shoals, Gulf of Maine. J Mar Biol Assoc UK 68:639-658

Lynn DH, Small EB (2000) Phylum Ciliophora. In: Lee JJ, Leedale GF, Bradbury P (eds) An illustrated guide to the Protozoa, 2nd edn. Society of Protozoologists, Lawrence, KS, p 371-656

Meyer B, Atkinson A, Stübing D, Oettl B, Hagen W, Bathmann U (2002) Feeding and energy budgets of Antarctic krill Euphausia superba at the onset of winter. I. Furcilia III larvae. Limnol Oceanogr 47:943-952

Montagnes DJS, Lynn DH (1987) A quantitative protargol stain (qps) for ciliates: method description and test of its quantitative nature. Mar Microb Food Webs 2:83-93

Montagnes DJS, Lynn DH (1991) Taxomony of Choreotrichs, the major marine planktonic ciliates, with emphasis on the aloricate forms. Mar Microb Food Webs 5:59-74

Montagnes DJS, Lynn DH, Stoecker DK, Small EB (1988) Taxonomic descriptions of one new species and redescriptions of four species in the Family Strombidiiae (Ciliophora, Oligotrichida). J Protozool 35:189-197

Nakamura Y, Turner JT (1997) Predation and respiration by the small cyclopoid copepod Oithona similis: How important is feeding on ciliates and heterotrophic flagellates? J Plankton Res 19:1275-1288

Pakhomov EA, Atkinson A, Meyer B, Oettl B, Bathmann U (2004) Daily rations and growth of larval krill Euphausia superba in the Eastern Bellingshausen Sea during austral

Editorial responsibility: Robert Sanders,

Philadelphia, Pennsylvania, USA autumn. Deep-Sea Res II 51:2185-2198

Pasternak AF, Schnack-Schiel SB (2001) Feeding patterns of dominant Antarctic copepods: an interplay of diapause, selectivity, and availability of food. Hydrobiologia 453: 25-36

Perissinotto R, Gurney L, Pakhomov EA (2000) Contribution of heterotrophic material to diet and energy budget of Antarctic krill, Euphausia superba. Mar Biol 136:129-135

Petz W, Song W, Wilbert N (1995) Taxonomy and ecology of the ciliate fauna (Protozoa, Ciliophora) in the endopelagial and pelagial of the Weddell Sea, Antarctica. Stapfia 40:1-233

Porter KG, Feig YS (1980) The use of DAPI for identifying and counting aquatic microflora. Limnol Oceanogr 25:943-948

Price HJ, Boyd KR, Boyd CM (1988) Omnovorous feeding behavior of the Antarctic krill Euphausia superba. Mar Biol 97:67-77

Quetin LB, Ross RM, Clarke A (1994) Krill energetics: seasonal and environmental aspects of the physiology of Euphausia superba. In: El-Sayed S (ed) Southern Ocean ecology: the BIOMASS perspective. Cambridge University Press, Cambridge, p 165-184

Rivkin RB (1991) Seasonal patterns of planktonic production in McMurdo Sound, Antarctica. Am Zool 31:5-16

Sabatini M, Kiørboe T (1994) Egg production, growth and development of the cyclopoid copepod Oithona similis. J Plankton Res 16:1329-1351

Sanders RW, Wickham SA (1993) Planktonic protists and metazoa: predation, food quality and population control. Mar Microb Food Webs 7:197-223

SAS Institute (1989) SAS/STAT users guide, version 6, 4th edn, Vol 1 \& 2. SAS Institute, Cary, NC

Skibbe O (1994) An improved quantitative protargol stain for ciliates and other planktonic protists. Arch Hydrobiol 130:339-347

Vaqué D, Agusti S, Duarte CM (2004) Response of bacterial grazing rates to experimental manipulation of an Antarctic coastal nanoflagellate community. Aquat Microb Ecol 36:41-52

Wickham SA (1995) Trophic relations between cyclopoid copepods and ciliated protists: complex interactions link the microbial and classic food webs. Limnol Oceanogr 40: $1173-1181$

Submitted: May 9, 2006; Accepted: September 6, 2006 Proofs received from author(s): November 15, 2006 